\title{
Purification and Characterization of Cell-associated Glucosyltransferase Synthesizing Water-insoluble Glucan from Serotype $c$ Streptococcus mutans
}

\author{
By SHIGEYUKI HAMADA, ${ }^{1}{ }^{*}$ TOSHIO HORIKOSHI, ${ }^{1}$ \\ TAKAHIRO MINAMI, ${ }^{1}$ NOBUO OKAHASHI ${ }^{2}$ AND TOSHIHIKO KOGA ${ }^{2}$ \\ ${ }^{1}$ Department of Oral Microbiology, Osaka University Faculty of Dentistry, Suita, \\ Osaka 565, Japan \\ ${ }^{2}$ Department of Dental Research, the National Institute of Health, Shinagawa-ku, \\ Tokyo 141, Japan
}

(Received 8 June 1988; accepted 9 November 1988)

\begin{abstract}
Strains of Streptococcus mutans (serotypes $c, e$ and $f$ ) were found to possess high levels of glucosyltransferase (GTase) activity, both cell-associated and in the culture medium, when grown in either sucrose-free or sucrose-containing broth media. The cell-associated GTase of $S$. mutans MT8148 (serotype $c$ ) was effectively extracted by treatment with $8 \mathrm{M}$-urea at $25^{\circ} \mathrm{C}$ for $1 \mathrm{~h}$. Approximately $95 \%$ of the GTase activity was solubilized by this treatment. The crude extract was purified by DEAE-Sephacel and hydroxylapatite column chromatography. For comparison, extracellular GTase was also purified from the culture supernatant of the same strain by ammonium sulphate precipitation, chromatofocusing and hydroxylapatite chromatography. The molecular masses of the cell-associated and extracellular GTase proteins were similar $(156 \mathrm{kDa})$ as determined by SDS-PAGE. However, the $\mathrm{pH}$ optima for maximum GTase activity were different: $\mathrm{pH} 6.7$ to 7.0 for the cell-associated enzyme and $\mathrm{pH} 5.5$ to 6.5 for the extracellular enzyme. The product of cell-associated GTase from sucrose was almost exclusively water-insoluble glucan. On the other hand, extracellular GTase produced mainly water-soluble glucan from sucrose. This indicates that GTase synthesizing water-insoluble glucan is present primarily in a cell-associated form in serotype $c S$. mutans. Insoluble glucan synthesis by the cellassociated GTase from sucrose was not enhanced by addition of primer dextran T10 to the reaction mixture. The extracellular and cell-associated GTases were immunologically unrelated as determined by ELISA using monoclonal antibodies.
\end{abstract}

\section{INTRODUCTION}

The mutans streptococci Streptococcus mutans and Streptococcus sobrinus have been implicated as primary causative agents of dental caries in humans and in experimental animals. The ability of mutans streptococci to attach firmly to the acquired pellicle on the tooth surface in the presence of dietary sucrose, and to form acids by fermentation of sugars are considered to be associated with its cariogenic potential. Among these factors, insoluble-glucan synthesis by $S$. mutans and $S$. sobrinus is a major determinant of pathogenicity (Hamada \& Slade, 1980): studies have clearly indicated that mutants of $S$. mutans that had lost the ability to synthesize insoluble glucan display reduced cariogenicity in experimental animals (Koga et al., 1986).

Strains of $S$. sobrinus (serotype $d$ and $g$ ) have been used in many experimental studies. This is mainly because they adhere firmly and reproducibly when sucrose is provided (Hamada et al., $1984 \mathrm{~b}$ ). The strains synthesize multiple forms of extracellular glucosyltransferases (GTases) differing in molecular mass, isoelectric points, immunochemical specificity, and the nature of

Abbreviations: FTase, fructosyltransferase: GTase, glucosyltransferase; PAS, periodic acid/Schiff. 
product glucans (Mukasa, 1986). Certain GTase(s) can bind to the cell surface of mutans streptococci and promote cellular adherence via insoluble glucans synthesized de novo from sucrose (Hamada \& Slade, 1980). Adherent glucan is produced from sucrose by the combined action of GTase-S that synthesizes water-soluble glucan and GTase-I that synthesizes waterinsoluble glucan (Inoue et al., 1982).

Serotype $c S$. mutans can be the most prevalent in humans of the various serotypes of $S$. mutans. Ample evidence indicates that serotype $e$ and $f$ strains are very similar to serotype $c$ strains in terms of various common physiological and immunological properties, with the exception of the immunochemical specificity of the cell wall polysaccharide antigen (Coykendall \& Gustafson, 1986; Hamada \& Slade, 1980).

Studies concerning the GTase system of $S$. mutans have not been as extensive as those on S. sobrinus. Most investigations have been concerned with extracellular GTase that can synthesize mainly water-soluble glucans (Mukasa, 1986), although GTases synthesizing insoluble glucan have been isolated from the culture supernatant of $S$. mutans strains (Kuramitsu \& Wondrack, 1983; Mukasa et al., 1985). Recently, we found that high levels of GTase activity are present in a cell-associated form as well as in an extracellular form in serotype $c S$. mutans. However, the nature of the cell-associated GTase remains to be elucidated. We have also shown that cellassociated GTase of serotype $c$ strains can be extracted very effectively by $8 \mathrm{M}$-urea, and purified chromatographically to homogeneity. This paper deals with the isolation, purification and characterization of cell-associated GTase of an $S$. mutans strain and its comparison with extracellular GTase.

\section{METHODS}

Bacterial strains and cultivation. S. mutans strains MT8148 (serotype $c$ ), MT4245 (e) and MT4251 $(f)$, and $S$. sobrinus strains OMZ176 $(d)$ and $6715(g)$ were used in this study. The first three strains were clinical isolates from carious lesions of Japanese children, while the latter two strains were from our culture collection at the Department of Oral Microbiology, Osaka University Faculty of Dentistry. The organisms were cultivated in commercially available culture media such as Todd-Hewitt (TH) broth (Difco) or Brain Heart Infusion (BHI) broth (Difco) at $37^{\circ} \mathrm{C}$ for $18 \mathrm{~h}$. Our previous studies indicated that TH broth contains trace amounts of sucrose, while BHI broth is essentially free from sucrose (Hamada \& Torii, 1978). For mass cultivation of organisms, TTY broth, which is a complex but sucrose-free medium (Hamada \& Torii, 1978), was used instead of BHI broth because of its increased yield of cells.

Measurement of GTase and FTase activities. GTase activity was determined as described by Koga et al. (1986). In brief, conversion of the glucosyl moiety of $\left[{ }^{14} \mathrm{C}\right]$ sucrose to methanol-insoluble glucan was measured. The standard reaction mixture contained $10 \mathrm{mM}-\left[{ }^{14} \mathrm{C}-\right.$ glucose $]$ sucrose $\left[0.05 \mathrm{Ci} \mathrm{mol}^{-1}\left(1.85 \mathrm{GBq} \mathrm{mol}^{-1}\right)\right.$; New England Nuclear] and $20 \mu \mathrm{M}$-dextran T10 in $20 \mu \mathrm{l} 0.1 \mathrm{M}$-potassium phosphate buffer ( $\mathrm{pH} \mathrm{6.0)}$. After these mixtures had been incubated for $1 \mathrm{~h}$ at $37^{\circ} \mathrm{C}$, they were spotted on a filter-paper square $(1.5 \times 1.5 \mathrm{~cm})$, and were dried in air. The squares were washed three times with methanol, dried, and immersed in scintillation fluid to determine the amount of $\left[{ }^{14} \mathrm{C}\right.$ glucan synthesized. One unit (U) of GTase activity was defined as the amount of enzyme required to incorporate $1.0 \mu \mathrm{mol}$ of glucose residue from the sucrose molecule into glucan min $^{-1}$ under the conditions described above.

Fructosyltransferase (FTase) activity was assayed similarly using $10 \mathrm{mM}-\left[{ }^{14} \mathrm{C}-\right.$ fructose $]$ sucrose $\left[0.05 \mathrm{Ci} \mathrm{mol}^{-1}\right.$ (1.85 GBq mol $\left.{ }^{-1}\right)$; New England Nuclear] in $0.1 \mathrm{M}$-potassium phosphate buffer (pH 6.0). Enzyme activity was determined by measuring incorporation of label into fructan as described above for GTase activity

Differential estimation of the production of water-soluble and water-insoluble glucan. Samples containing $50 \mathrm{mU}$ of GTase activity were incubated in $1 \%(\mathrm{w} / \mathrm{v})$ solution in $0.1 \mathrm{M}$-potassium phosphate buffer, $\mathrm{pH} 6.0$, for $18 \mathrm{~h}$ at $37^{\circ} \mathrm{C}$. Sodium azide $(0.1 \%)$ was included in the reaction mixture as a preservative. After incubation, the reaction mixture was centrifuged at $1600 \mathrm{~g}$ for $15 \mathrm{~min}$ at $4^{\circ} \mathrm{C}$. The precipitate (insoluble polysaccharide) was washed three times with excess distilled water and its sugar content was measured. Cold ethanol $(2.5$ vols $)$ was added to the supernatant; the mixture was incubated at $4^{\circ} \mathrm{C}$ for $2 \mathrm{~h}$, and centrifuged at $1600 \mathrm{~g}$ for $15 \mathrm{~min}$ at $4{ }^{\circ} \mathrm{C}$. The precipitate was dissolved in distilled water, and ethanol precipitation was repeated as described above. This second precipitate was redissolved in distilled water, and was designated soluble polysaccharide. The sugar content of these polysaccharides was estimated colorimetrically by the anthrone method (Scott \& Melvin, 1953).

Extraction of cell-associated GTase. Various methods of extraction or release of cell-associated GTase from cells of $S$. mutans were attempted. Cells of $S$. mutans MT8148 from $180 \mathrm{ml}$ TTY-grown overnight cultures were washed extensively with $10 \mathrm{~mm}$-sodium phosphate buffer $(\mathrm{pH} 6.0)$ by centrifugation. The centrifuged pellet was 
suspended in $5 \mathrm{ml}$ of extraction fluid, and incubated at 4 or $25^{\circ} \mathrm{C}$ for $1 \mathrm{~h}$ with occasional shaking. The extract was

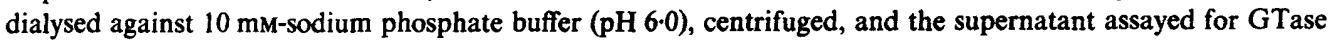
activity.

Purification of GTases. Extracellular GTase was purified from the culture supernatant of a TTY broth culture (81) of $S$. mutans MT8148. Crude GTase was obtained by $50 \%$ (saturation) ammonium sulphate precipitation, chromatofocusing on a Polybuffer exchanger PBE94 (Pharmacia), and subsequent hydroxylapatite (HA) (Bio-Gel HTP; Bio-Rad) chromatography essentially according to the description of Sato et al. (1984).

Cell-associated GTase was purified by using DEAE-Sephacel (Pharmacia) and hydroxylapatite chromatography. Crude enzyme, extracted from fresh cells which had been grown overnight in TTY broth (81) was concentrated by $60 \%$ (saturation) ammonium sulphate precipitation, dialysed against $0.01 \mathrm{M}$-sodium phosphate buffer ( $\mathrm{pH} 7 \cdot 5)$, and loaded onto a DEAE-Sephacel column $(2.5 \times 13 \mathrm{~cm})$. After washing with sodium phosphate buffer $(0.05 \mathrm{M}, \mathrm{pH} 7.5 ; 225 \mathrm{ml})$, bound proteins were eluted with a linear gradient of 0 to $1.0 \mathrm{M}-\mathrm{NaCl}$. Fractions ( $15 \mathrm{ml}$ ) were collected and their $A_{280}$ was measured in a Hitachi model 200-20 spectrophotometer. Enzyme activity was determined as described above. Fractions containing GTase were pooled, dialysed against sodium phosphate buffer ( $0.01 \mathrm{M}, \mathrm{pH} 6.0)$, and the GTase solution was applied onto an hydroxylapatite column $(1.0 \times 13 \mathrm{~cm})$. The column was first eluted with $225 \mathrm{ml} 0.01 \mathrm{M}$-sodium phosphate buffer ( $\mathrm{pH} \mathrm{6.0)}$ ), and then eluted step-wise with $0.01 \mathrm{M}(90 \mathrm{ml}), 0.2 \mathrm{M}(165 \mathrm{ml}), 0.26 \mathrm{M}(135 \mathrm{ml})$ and $0.5 \mathrm{M}(255 \mathrm{ml})$ sodium phosphate buffer $(\mathrm{pH} 6.0)$ at a flow rate of $2 \mathrm{ml} \mathrm{min}{ }^{-1}$. The $A_{280}$ and enzyme activity of each fraction (15 ml per tube) were measured as described above.

$S D S-P A G E$. This was done as previously described (Koga et al., 1986). Crude and purified enzyme proteins $(0 \cdot 6$ to $147 \mu \mathrm{g}$ ) were treated at $100{ }^{\circ} \mathrm{C}$ for $5 \mathrm{~min}$ or $37^{\circ} \mathrm{C}$ for $30 \mathrm{~min}$ in $0.01 \mathrm{M}$-Tris/ $\mathrm{HCl}$ buffer (pH 6.8) containing $1 \%$ (w/v) SDS, $1 \%(\mathrm{w} / \mathrm{v}) 2$-mercaptoethanol and $20 \%(\mathrm{v} / \mathrm{v})$ glycerol. Electrophoresis was done at $5 \mathrm{~mA}$ per gel at $4{ }^{\circ} \mathrm{C}$ for $4 \mathrm{~h}$ using a $7.5 \%(\mathrm{w} / \mathrm{v})$ resolving and a $3 \%(\mathrm{w} / \mathrm{v})$ stacking gel $(8.5 \times 7.7 \times 0.1 \mathrm{~cm})$ containing $0.1 \%(\mathrm{w} / \mathrm{v}) \mathrm{SDS}$. Proteins used as molecular mass markers were ferritin $(220 \mathrm{kDa})$, phosphorylase $(94 \mathrm{kDa})$, bovine serum albumin $(67 \mathrm{kDa})$, catalase $(60 \mathrm{kDa})$, ovalbumin $(43 \mathrm{kDa})$ and lactate dehydrogenase $(36 \mathrm{kDa})$. Proteins were stained with Coomassie brilliant blue R-250. To detect enzyme activities, gels were incubated at $37{ }^{\circ} \mathrm{C}$ for $18 \mathrm{~h}$ in buffered $2 \%$ $(\mathrm{w} / \mathrm{v})$ sucrose $(\mathrm{pH} 6.0)$. In addition, gels were incubated at $37^{\circ} \mathrm{C}$ for $18 \mathrm{~h}$ with $1 \%(\mathrm{w} / \mathrm{v})$ raffinose in potassium phosphate buffer (0.05 M, pH 6.0) to detect FTase (Russell, 1979). The polysaccharides synthesized were stained with the periodic acid/Schiff (PAS) reagent as described by Zacharius et al. (1969).

Determination of $\mathrm{pI}$. GTase proteins $(10$ to $20 \mu \mathrm{g})$ were subjected to analytical isoelectric focusing on an Ampholine polyacrylamide gel plate (LKB) with a pH range of 3.5 to 9.5 at $300 \mathrm{~V}$ for $2 \mathrm{~h}$. Enzyme activity was visualized by the PAS method after incubation in potassium phosphate buffered sucrose at $37^{\circ} \mathrm{C}$ for $18 \mathrm{~h}$ as described above.

Determination of optimum $p H$ and $K_{m}$. The optimum pH of GTases was determined by measuring GTase activity in half-strength Mcllvain buffer ( $\mathrm{pH} 4.5$ to $7 \cdot 5$ ). The $K_{\mathrm{m}}$ value for sucrose was calculated as described previously (Sato et al., 1984).

Enzyme immunoassay. Immunological specificity of GTase protein was examined by the enzyme-linked immunosorbent assay (ELISA) method essentially as described previously by Furuta et al. (1983). Mouse monoclonal antibodies directed to purified extracellular and cell-associated GTases of $S$. mutans MT8148 were elaborated by the PEG-induced fusion of mouse myeloma cells SP2/0 and spleen cells from BALB/c mice immunized with these purified enzyme proteins, respectively, following the description of Hamada et al. (1984a). Furthermore, rabbits were also immunized by intramuscular injections of the SDS-PAGE-separated $156 \mathrm{kDa}$ protein of extracellular and cell-associated GTases suspended in Freund's complete adjuvant (Difco). The antisera obtained gave a sharp precipitation band with the homologous extracellular and cell-associated GTases only. The immunoglobulin fraction was isolated from the antisera by repeated $33 \%$ (saturation) ammonium sulphate precipitations. Both monoclonal and polyclonal antibodies specific for extracellular and cell-associated GTases were used for ELISA to determine the immunological specificities of these GTases. In addition, immunological reactivity of the purified GTases was examined by using mouse monoclonal antibodies specific for lipoteichoic acid (Hamada et al., 1984a) or a $190 \mathrm{kDa}$ surface protein antigen, PAc, of S. mutans MT8148 (kindly supplied by M. Ohta, Department of Dental Research, National Institute of Health, Tokyo).

\section{RESULTS}

\section{Localization of GTase in S. mutans}

$S$. mutans serotypes $c, e$ and $f$ produced both extracellular and cell-associated GTase when grown in either BHI or TH broth (Table 1). This indicates that no significant change in GTase localization in $S$. mutans (serotype $c, e$ and $f$ ) occurred in these culture media. In contrast, BHIgrown organisms of $S$. sobrinus (serotypes $d$ and $g$ ) released GTase almost exclusively into the culture supernatant (Table 1), whereas TH-grown organisms of these serotypes possessed strong cell-associated GTase activity. 
Table 1. Localization of GTase activity of S. mutans and S. sobrinus strains grown in BHI and TH broth media

Test strains were grown in 1 litre of BHI or TH broth at $37^{\circ} \mathrm{C}$ for $18 \mathrm{~h}$. Cultures were centrifuged, and the extracellular GTase activity of the supernatant was determined by using $\left[{ }^{14} \mathrm{C}-\mathrm{glucose}\right]$ sucrose. Cellassociated GTase activity was assayed in the centrifuged pellet: cells were washed with deionized water, resuspended in potassium phosphate buffer and used for the enzyme activity assay as described in Methods.

\begin{tabular}{|c|c|c|c|c|c|}
\hline$\underset{\text { (serotype) }}{\text { Strain }}$ & Medium & $\begin{array}{c}\text { Final } \\
\text { pH }\end{array}$ & $\begin{array}{c}\text { Extra- } \\
\text { cellular } \\
\text { GTase } \\
\left(\mathrm{mU} \mathrm{ml}^{-1}\right)\end{array}$ & $\begin{array}{c}\text { Cell- } \\
\text { associated } \\
\text { GTase } \\
\left(\mathrm{mU} \mathrm{ml}^{-1}\right)\end{array}$ & $\mathrm{EX} / \mathrm{CA}^{*}$ \\
\hline \multicolumn{6}{|l|}{$S$. mutans } \\
\hline MT8148 (c) & $\begin{array}{l}\text { BHI } \\
\text { TH }\end{array}$ & $\begin{array}{l}5 \cdot 6 \\
5 \cdot 6\end{array}$ & $\begin{array}{l}10 \cdot 1 \\
14.5\end{array}$ & $\begin{array}{l}2 \cdot 4 \\
3 \cdot 6\end{array}$ & $\begin{array}{l}4 \cdot 2 \\
4 \cdot 0\end{array}$ \\
\hline MT4245 (e) & $\begin{array}{l}\text { BHI } \\
\text { TH }\end{array}$ & $\begin{array}{l}5.5 \\
5.5\end{array}$ & $\begin{array}{l}17.5 \\
19.5\end{array}$ & $\begin{array}{l}1 \cdot 4 \\
2 \cdot 1\end{array}$ & $\begin{array}{r}12.5 \\
9.3\end{array}$ \\
\hline $\operatorname{MT4251}(f)$ & $\begin{array}{l}\text { BHI } \\
\text { TH }\end{array}$ & $\begin{array}{l}5.4 \\
5.5\end{array}$ & $\begin{array}{l}16.7 \\
12.0\end{array}$ & $\begin{array}{l}1.5 \\
3.3\end{array}$ & $\begin{array}{r}11 \cdot 1 \\
3.6\end{array}$ \\
\hline \multicolumn{6}{|l|}{ S. sobrinus } \\
\hline OMZ176 (d) & $\begin{array}{l}\text { BHI } \\
\text { TH }\end{array}$ & $\begin{array}{l}5.8 \\
5.7\end{array}$ & $\begin{array}{r}13 \cdot 1 \\
3 \cdot 1\end{array}$ & $\begin{array}{r}0.5 \\
11.2\end{array}$ & $\begin{array}{c}26.2 \\
0.28\end{array}$ \\
\hline 6715 & $\begin{array}{l}\text { BHI } \\
\text { TH }\end{array}$ & $\begin{array}{l}5.9 \\
6.0\end{array}$ & $\begin{array}{r}11.8 \\
1.9\end{array}$ & $\begin{array}{l}0.2 \\
3.2\end{array}$ & $\begin{array}{c}59.0 \\
0.59\end{array}$ \\
\hline
\end{tabular}

\footnotetext{
* Ratio of extracellular GTase activity (EX) to cell-associated GTase activity (CA) in the BHI- or TH-grown cultures.
}

Table 2. Purification of extracellular GTase from S. mutans MT8148

\begin{tabular}{|c|c|c|c|c|c|}
\hline $\begin{array}{l}\text { Purification } \\
\text { step }\end{array}$ & $\begin{array}{l}\text { Total } \\
\text { protein } \\
\text { (mg) }\end{array}$ & $\begin{array}{c}\text { Total } \\
\text { GTase activity } \\
\text { (U) }\end{array}$ & $\begin{array}{c}\text { Specific } \\
\text { GTase activity } \\
\left(\mathrm{U} \mathrm{mg}^{-1}\right)\end{array}$ & $\begin{array}{c}\text { Recovery } \\
(\%)\end{array}$ & $\begin{array}{l}\text { Purification } \\
\text { (-fold) }\end{array}$ \\
\hline Culture supernatant ( 81 ) & 81300 & $67 \cdot 3$ & 0.0008 & 100 & 1 \\
\hline $\begin{array}{l}\text { Ammonium sulphate } \\
\text { (50\% saturation) }\end{array}$ & 600 & $37 \cdot 7$ & 0.0628 & 56 & 79 \\
\hline Chromatofocusing & $22 \cdot 7$ & $8 \cdot 67$ & 0.382 & 13 & 478 \\
\hline Hydroxylapatite & 1.66 & $2 \cdot 32$ & 1.40 & 3 & 1750 \\
\hline
\end{tabular}

\section{Purification of extracellular GTase}

Purification of extracellular GTase from the culture supernatant of TTY-grown $S$. mutans strain MT8148 was done by ammonium sulphate precipitation, chromatofocusing on a Polybuffer exchanger PBE94 column, and subsequent hydroxylapatite chromatography (elution profile not shown). The recovery of purified extracellular GTase was $3.0 \%$, and the degree of purification was 1750-fold, as compared to the GTase activity in the original culture supernatant. The specific activity of the purified GTase was $1.40 \mathrm{U}$ (mg protein) ${ }^{-1}$ (Table 2).

\section{Purification and characterization of cell-associated GTase}

In the second phase of our study, cell-associated GTase was extracted from cells of $S$. mutans MT8148 which had been grown in sucrose-free TTY broth. Treatment of cells with $8 \mathrm{M}$-urea at $25^{\circ} \mathrm{C}$ for $1 \mathrm{~h}$ resulted in extensive liberation of cell-associated GTase (Table 3). Other extraction methods such as $6 \mathrm{M}$-guanidine. $\mathrm{HCl}, 1 \mathrm{M}-\mathrm{NaCl}$ or sonication of the cells released significant, but far smaller quantities of cell-associated GTase by comparison. The crude extract of $S$. mutans MT8148 was then analysed by SDS-PAGE, and the enzyme activities detected as described in Methods. The extract of whole cells was found to contain significant quantities of GTase and FTase (Fig. 1). 


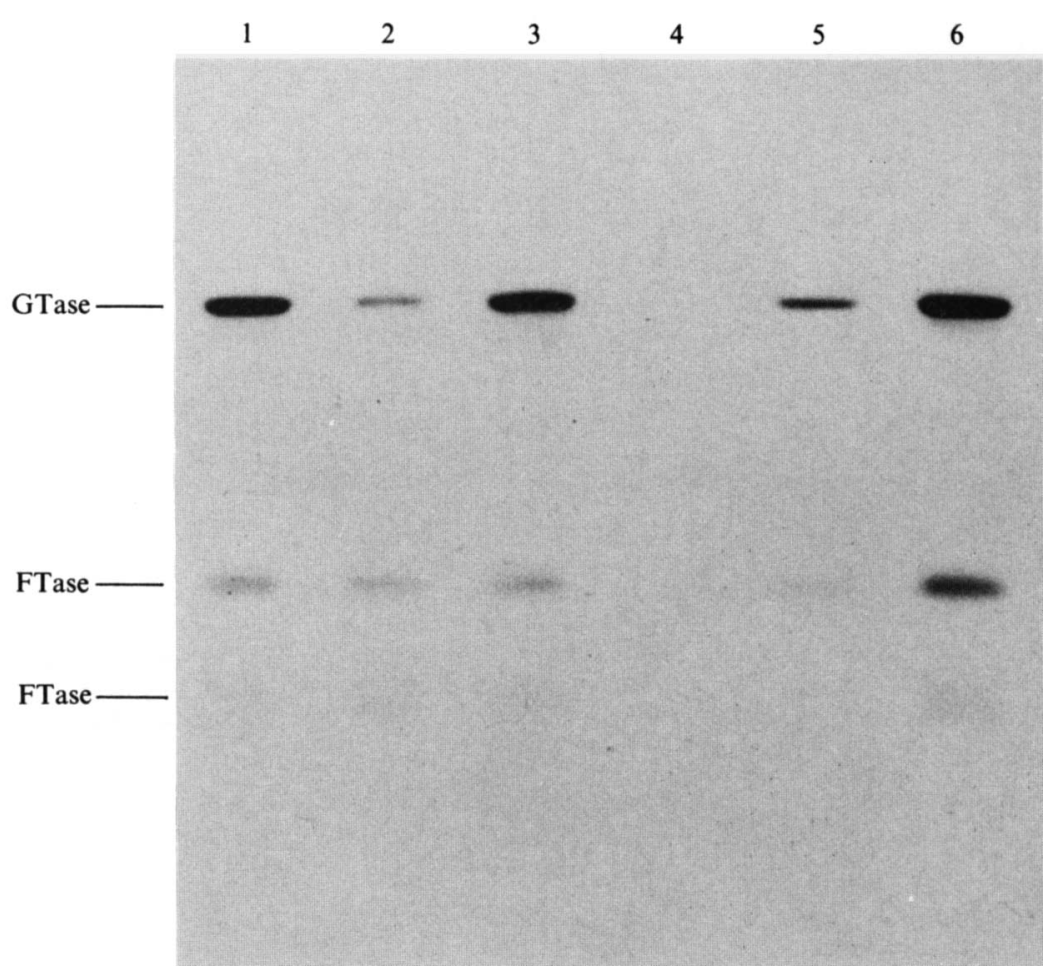

Fig. 1. PAS staining of SDS-PAGE for GTase and FTase activities of extracts of S. mutans MT8148. The gel was incubated at $37^{\circ} \mathrm{C}$ for $18 \mathrm{~h}$ in potassium phosphate buffered sucrose $(2 \%, \mathrm{w} / \mathrm{v})$ without primer dextran, and the polysaccharides synthesized were stained by the PAS method. The samples applied were $8 \mathrm{M}$-urea extract at $25^{\circ} \mathrm{C}$ (lane 1), $8 \mathrm{M}$-urea extract at $4^{\circ} \mathrm{C}(2), 6 \mathrm{M}$-guanidine. $\mathrm{HCl}$ extract (3), $1 \mathrm{M}-\mathrm{NaCl}$ extract (4), ultrasonic extract (5) and concentrated culture supernatant (6).

Table 3. Extraction of cell-associated GTase from S. mutans MT8148 cells grown in TTY broth: comparison of the efficiency of the various extraction methods

Cells were recovered from $180 \mathrm{ml}$ TTY culture by centrifugation, washed with water, and suspended in $5 \mathrm{ml} 8 \mathrm{M}$-urea, $6 \mathrm{M}$-guanidine. $\mathrm{HCl}$ or $1 \mathrm{M}-\mathrm{NaCl}$. After treatment as described above, each extract was dialysed against $0.01 \mathrm{M}$-sodium phosphate buffer (pH 6.0) and centrifuged at $25000 \mathrm{~g}$ for $15 \mathrm{~min}$ at $4^{\circ} \mathrm{C}$; the supernatant was then used for measurement of GTase activity. Total cell-associated GTase was assayed in untreated cells. Recovery is expressed as a percentage of the activity of extracts to the total GTase activity of whole cells of $S$. mutans.

$\begin{array}{lccc}\text { Extraction } & \text { Treatment } & \begin{array}{c}\text { Specific } \\ \text { GTase activity } \\ \left(\mathrm{U} \mathrm{mg}^{-1}\right)\end{array} & \begin{array}{c}\text { Recovery } \\ (\%)\end{array} \\ 8 \mathrm{M} \text {-Urea } & 25^{\circ} \mathrm{C}, 1 \mathrm{~h} & 0.98 & 95.1 \\ & 4^{\circ} \mathrm{C}, 1 \mathrm{~h} & 0.29 & 28.8 \\ 6 \mathrm{M}-\text { Guanidine. } \mathrm{HCl} & 4^{\circ} \mathrm{C}, 1 \mathrm{~h} & 0.44 & 52.8 \\ \text { 1 M-NaCl } & 4^{\circ} \mathrm{C}, 1 \mathrm{~h} & 0.45 & 7.3 \\ \text { Sonication } & 4^{\circ} \mathrm{C}, 3 \mathrm{~min} & 0.09 & 20.0 \\ (20 \mathrm{kHz}, 200 \mathrm{~W}) & & & \end{array}$

Crude GTase extracted by $8 \mathrm{M}$-urea from cells grown in TTY medium was purified by DEAESephacel, followed by hydroxylapatite chromatography. A typical elution profile from DEAESephacel is shown in Fig. 2. Fractions containing GTase and FTase activities eluted at about $0.6 \mathrm{M}-\mathrm{NaCl}$. FTase and GTase were then clearly separated by hydroxylapatite chromatography; 


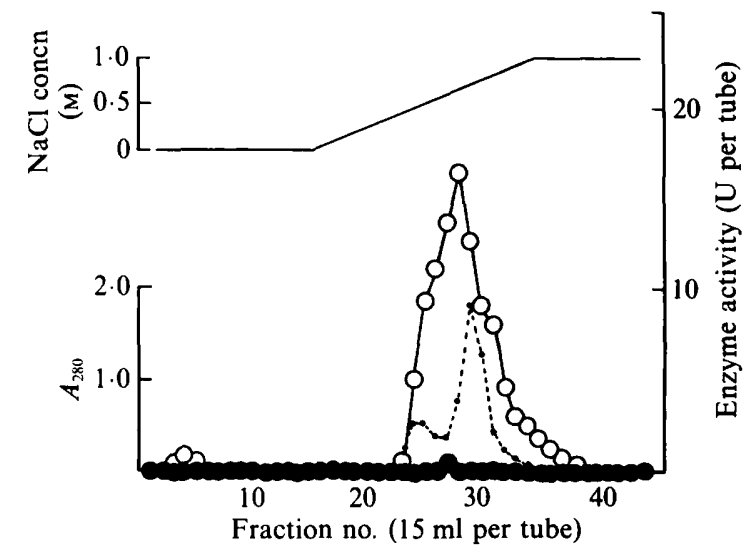

Fig. 2. DEAE-Sephacel column chromatography of crude cell-associated GTase of $S$. mutans MT8148. Cells grown in TTY broth (81) were extracted with $8 \mathrm{M}$-urea at $25^{\circ} \mathrm{C}$ for $1 \mathrm{~h}$. The crude extract was applied to a DEAE-Sephacel column $(2.5 \times 13 \mathrm{~cm})$, and the column was eluted with sodium phosphate buffer ( $0.05 \mathrm{M}, \mathrm{pH} 7.5$ ), followed by a linear gradient of 0 to $1.0 \mathrm{M}-\mathrm{NaCl}$ (flow rate $30 \mathrm{ml} \mathrm{h}^{-1}$ ). The enzyme activity of each fraction was measured using $\left[{ }^{14} \mathrm{C}\right]$ sucrose., FTase; O, GTase; ---, $A_{280}$; $-\mathrm{NaCl}$ concn.

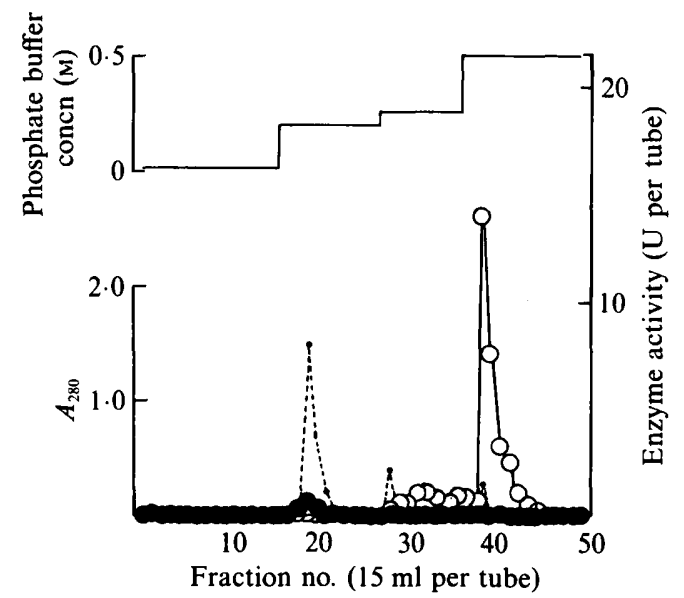

Fig. 3. Chromatography of partially purified cell-associated GTase on a hydroxylapatite column. Partially purified GTase isolated by DEAE-Sephacel chromatography was applied to an hydroxylapatite column $(1 \times 13 \mathrm{~cm})$, and the column was eluted step-wise with $0 \cdot 01,0 \cdot 2.0 \cdot 26$ and $0.5 \mathrm{M}$-sodium phosphate buffer (pH 6.0) (flow rate $2 \mathrm{ml} \mathrm{min}^{-1}$ )., , FTase; O, GTase; ---, $A_{280} ;-$, phosphate buffer concn.

a peak of GTase was obtained by elution with $0.5 \mathrm{M}$-sodium phosphate buffer, pH 6.0 (Fig. 3). SDS-PAGE of purified extracellular and cell-associated GTase preparations gave single protein bands with very similar molecular masses $(156 \mathrm{kDa})$ as determined by SDS-PAGE (Fig. 4). Although the degree of purification of cell-associated GTase was only 3.5-fold, the absolute specific activity of GTase extracted with $8 \mathrm{M}$-urea was very high [2.01 $\mathrm{U}(\mathrm{mg} \text { protein })^{-1}$ ] indicating that urea extraction is a useful method of obtaining cell-associated GTase from $S$. mutans (Table 4). The GTase activity was completely inactivated after treatment at $80^{\circ} \mathrm{C}$ for $5 \mathrm{~min}$; however, only a slight decrease in GTase activity was found after treatment at $60^{\circ} \mathrm{C}$ for $30 \mathrm{~min}$. Synthesis of insoluble glucan by the cell-associated GTase from sucrose was not enhanced by the presence of primer dextran T10 (results not shown). 


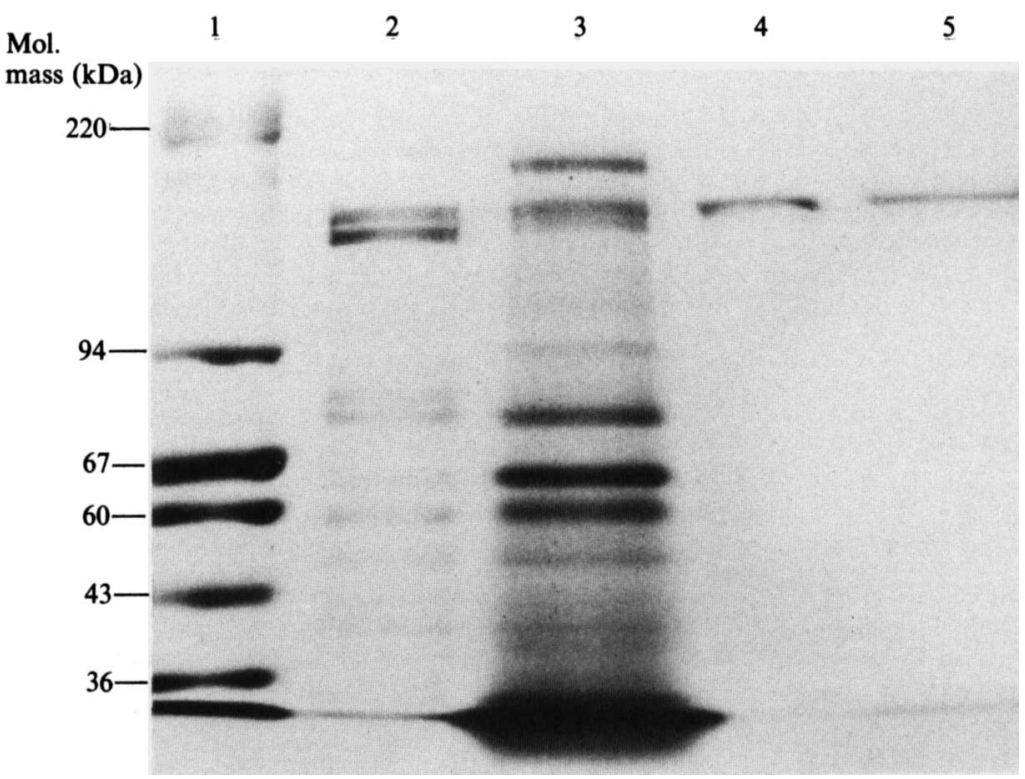

Fig. 4. SDS-PAGE of GTase preparations from $S$. mutans MT8148. SDS-PAGE was done at $5 \mathrm{~mA}$ per gel at $4{ }^{\circ} \mathrm{C}$ for $4 \mathrm{~h}$. Proteins were stained with Coomassie brilliant blue R-250. Molecular mass standard proteins are in lane 1 . The samples applied were crude urea-extract $(3.9 \mu \mathrm{g}$; lane 2$)$, culture supernatant (147 $\mu \mathrm{g}$ protein; lane 3$)$, purified cell-associated GTase $(0.6 \mu \mathrm{g}$; lane 4$)$ and purified extracellular GTase (4.4 $\mu \mathrm{g}$; lane 5).

Table 4. Purification of cell-associated GTase from S. mutans MT8148

Cells recovered from TTY culture (8 l) were used for the extraction of cell-associated GTase.

$\begin{array}{lccccc}\begin{array}{c}\text { Purification } \\ \text { step }\end{array} & \begin{array}{c}\text { Total } \\ \text { protein } \\ (\mathrm{mg})\end{array} & \begin{array}{c}\text { Total } \\ \text { activity } \\ (\mathrm{U})\end{array} & \begin{array}{c}\text { Specific } \\ \text { activity } \\ \left(\mathrm{U} \mathrm{mg}^{-1}\right)\end{array} & \begin{array}{c}\text { Recovery } \\ (\%)\end{array} & \begin{array}{c}\text { Purification } \\ \text { (-fold) }\end{array} \\ \begin{array}{c}\text {-Urea extract } \\ \text { Ammonium sulphate }\end{array} & 207 & 417 & 2.01 & 100 & 1 \\ \begin{array}{l}60 \% \text { saturation) } \\ \text { AE-Sephacel }\end{array} & 119 & 260 & 2 \cdot 18 & 62 & 1 \cdot 1 \\ \text { droxylapatite } & 37 \cdot 4 & 85.9 & 2.30 & 21 & 1 \cdot 1 \\ & 4.71 & 32.8 & 6.96 & 8 & 3.5\end{array}$

Table 5. Characteristics of extracellular and cell-associated GTases from S. mutans MT8148

\begin{tabular}{lcc}
\multicolumn{1}{c}{ Property } & Extracellular & Cell-associated \\
GTase & GTase \\
Molecular mass (kDa) & 156 & 156 \\
pI & $7 \cdot 4$ & ND \\
pH optimum & $5 \cdot 5-6 \cdot 5$ & $6 \cdot 7-7 \cdot 0$ \\
$K_{\mathrm{m}}(\mathrm{mM})$ & $9 \cdot 1$ & $11 \cdot 1$ \\
Solubility of product glucan in water & $98 \cdot 2 \%$ soluble & $98 \cdot 3 \%$ insoluble
\end{tabular}

ND, Not determined.

\section{Comparison of extracellular and cell-associated GTases}

Purified preparations of extracellular and cell-associated GTases were compared in terms of molecular mass, pI, pH optimum, and in the water solubility of their product glucans (Table 5). Although the molecular masses of the enzymes are essentially similar, as described above, they 
Table 6. ELISA of extracellular and cell-associated GTases from S. mutans MT8148 with mouse monoclonal and rabbit polyclonal antibodies against GTases

Microtitre plates were coated with GTases $(100 \mu \mathrm{l} ; 10 \mu \mathrm{g}$ protein per ml of coating carbonate buffer) at $4{ }^{\circ} \mathrm{C}$ for $12 \mathrm{~h}$. The plates were washed, and $100 \mu \mathrm{l}$ of mouse monoclonal antibodies (diluted $10^{3}$-fold) or rabbit antibodies (diluted $10^{6}$-fold) to purified extracellular and cell-associated GTases were added: the plates were then incubated for $1 \mathrm{~h}$ at $25^{\circ} \mathrm{C}$. After unbound antibodies were washed off, alkalinephosphatase-labelled rabbit anti-mouse IgG or goat anti-rabbit IgG $(100 \mu \mathrm{l})$ was added and incubated at $25^{\circ} \mathrm{C}$ for $2 \mathrm{~h}$. After a second washing step p-nitrophenyl phosphate $(0.1 \mathrm{mg}$ in $100 \mu \mathrm{l})$ was added. The intensity of colour developed in $15 \mathrm{~min}$ was measured at $405 \mathrm{~nm}$ using a Titertek photometer.

\begin{tabular}{|c|c|c|c|c|}
\hline \multirow[b]{3}{*}{ Coating antigen } & \multicolumn{4}{|c|}{ Absorbance at $405 \mathrm{~nm}$} \\
\hline & \multicolumn{2}{|c|}{$\begin{array}{l}\text { Antibody to } \\
\text { cell-free GTase }\end{array}$} & \multicolumn{2}{|c|}{$\begin{array}{l}\text { Antibody to } \\
\text { cell-associated GTase }\end{array}$} \\
\hline & $\begin{array}{c}\text { Mouse } \\
\text { monoclonal }\end{array}$ & $\begin{array}{c}\text { Rabbit } \\
\text { polyclonal }\end{array}$ & $\begin{array}{c}\text { Mouse } \\
\text { monoclonal }\end{array}$ & $\begin{array}{c}\text { Rabbit } \\
\text { polyclonal }\end{array}$ \\
\hline $\begin{array}{l}\text { Extracellular } \\
\text { Crude GTase } \\
\text { Purified GTase }\end{array}$ & $\begin{array}{l}0.336 \\
0.890\end{array}$ & $\begin{array}{l}0.216 \\
1.005\end{array}$ & $\begin{array}{l}0.041 \\
0.069\end{array}$ & $\begin{array}{l}0.093 \\
0.127\end{array}$ \\
\hline $\begin{array}{l}\text { Cell-associated } \\
8 \mathrm{M} \text {-Urea extract } \\
\text { Purified GTase }\end{array}$ & $\begin{array}{l}0.125 \\
0.054\end{array}$ & $\begin{array}{l}0.173 \\
0.107\end{array}$ & $\begin{array}{l}0.115 \\
0.483\end{array}$ & $\begin{array}{l}0.248 \\
0.562\end{array}$ \\
\hline
\end{tabular}

differ in other properties, the most striking of which are $\mathrm{pH}$ optimum and solubility of their product glucans. Extracellular GTase had a lower pH optimum (pH 5.5 to 6.5) than cellassociated GTase (pH 6.7 to 7.0). The pI value of extracellular GTase was 7.4, while that of cellassociated GTase could not be determined because of the formation of a heavy aggregate during electrophoresis in the Ampholine gel. The glucan produced from sucrose by the extracellular enzyme was largely water-soluble, while the cell-associated enzyme synthesized almost exclusively a water-insoluble glucan.

The immunological specificity of the enzyme proteins was examined using an ELISA technique (Table 6). The extracellular GTase reacted strongly with mouse monoclonal and rabbit polyclonal anti-extracellular GTase antibodies, but not with monoclonal and polyclonal antibodies specific for purified cell-associated GTase. The converse was also true. These results indicate that the antigenic structures of these two enzyme proteins are entirely different. Furthermore, monoclonal and polyclonal antibodies to cell-surface proteins did not react with these GTases.

\section{DISCUSSION}

The present study has clearly shown that serotype $c S$. mutans possess a cell-associated GTase capable of synthesizing significant quantities of water-insoluble glucan from sucrose, and that this enzyme can be released from whole cells by treatment with $8 \mathrm{M}$-urea. Two forms of cellassociated GTase from the serotype $c S$. mutans strain GS-5 were isolated by Kuramitsu (1974). One enzyme was extracted by treatment with $1 \mathrm{M}-\mathrm{NaCl}$ from cells grown in $\mathrm{TH}$ broth. The other GTase was an intracellular enzyme released after disruption of cells. The enzyme extracted with $1 \mathrm{M}-\mathrm{NaCl}$ synthesized insoluble glucan from sucrose, and in this sense is similar to the cellassociated GTase which we obtained by extraction of whole cells of S. mutans MT8148 with 8 Murea. However, there are important differences between the two enzymes. For example, the former exhibited a broad $\mathrm{pH}$ optimum between $\mathrm{pH} 5$ and 7, with a maximum around $\mathrm{pH} 6$, while the latter exhibited a maximum $\mathrm{pH}$ of 6.7 to 7.0 . The $K_{\mathrm{m}}$ values of the enzymes are different also. Furthermore, in our experiments only a small portion of the GTase activity associated with cells of strain MT8148 could be extracted by $1 \mathrm{M}-\mathrm{NaCl}$, indicating that extraction with $8 \mathrm{M}$-urea is a far more effective method for the release of cell-associated GTase. 
More recently, Kuramitsu \& Wondrack (1983) isolated a water-insoluble glucan synthesizing GTase from the culture supernatant of $S$. mutans GS-5. Their extracellular GTase was reported to be primer-dependent; however, our cell-associated GTase synthesized primarily waterinsoluble glucan without requiring dextran T10. The presence of this primer decreased, rather than stimulated the synthesis of water-insoluble glucan. These results indicate that the GTases differ completely in terms of primer-dependency.

In addition to cell-associated GTase, growing cells of $S$. mutans MT8148 produce extracellular GTase(s). An extracellular GTase which synthesized mainly water-soluble glucan was purified to homogeneity. ELISA with monoclonal and polyclonal antibodies to the purified GTases of strain MT8148 (Baba et al., 1986) showed that these GTase proteins are antigenically unrelated (Table 6). It was also demonstrated that monoclonal antibodies raised against lipoteichoic acid and the surface protein antigen PAc of $S$. mutans MT8148 did not react significantly with the purified GTases (results not shown), indicating that these GTase preparations were not contaminated by cellular components such as lipoteichoic acid and PAc.

Mukasa et al. (1985) reported that a water-insoluble glucan synthesizing GTase was present in the culture supernatant of serotype $c S$. mutans strain Ingbritt. The purified enzyme had a molecular mass of $99 \mathrm{kDa}$ and was immunologically distinct from another extracellular watersoluble-glucan synthesizing GTase (molecular mass $151 \mathrm{kDa}$ ) from the same strain (Mukasa et al., 1982). The $99 \mathrm{kDa}$ GTase may be a breakdown product of the $156 \mathrm{kDa}$ cell-associated GTase. In this regard, Kenney \& Cole (1983) isolated an extracellular $153 \mathrm{kDa}$ GTase that produced insoluble glucan from sucrose as well as a water-soluble-glucan synthesizing $162 \mathrm{kDa}$ dextransucrase from $S$. mutans strain 3209 (serotype c). The $153 \mathrm{kDa}$ GTase that synthesizes water-insoluble glucan appears to be similar to our cell-associated GTase in terms of molecular mass and in the nature of the glucan produced from sucrose.

Genetic analysis has shown that serotype $c S$. mutans strains possess at least three GTase proteins (Curtiss, 1985). Several research groups have cloned GTase genes from strains of $S$. mutans belonging to serotypes $c$ or $e$. A GTase gene $(g t f A)$ was first cloned from $S$. mutans UAB 90 (serotype $c$ ), which produces a $55 \mathrm{kDa}$ protein (Robeson et al., 1983). Subsequently, similar genes were cloned from $S$. mutans LM7 (serotype e) (Pucci et al., 1987) and GS-5 (serotype $c$ ) (Burne et al., 1986). Another GTase gene, designated $g t f B$, was cloned from $S$. mutans GS-5 (serotype $c$ ) (Aoki et al., 1986). This gene codes for the GTase activity synthesizing water-insoluble glucan reported by Kuramitsu \& Wondrack (1983). Shiroza et al. (1987) suggested that the $g t f B$ gene encodes a strongly hydrophilic protein composed of 1475 amino acids. In this regard, we found that $S$. mutans cells which had been extracted with $8 \mathrm{M}$-urea exhibited a significantly increased hydrophobicity (results not shown). This also indicates that cell-associated GTase is a hydrophilic protein, in agreement with the report of Shiroza et al. (1987). Pucci et al. (1987) cloned the third GTase gene ( $g t f C)$, which encodes a $150 \mathrm{kDa}$ protein, from $S$. mutans LM7. The extracellular GTase of strain MT8148 reported here may be the protein encoded by $g t f C$. However, it remains to be determined whether $g t f B$ is the gene that codes for our cell-associated GTase-I. It would be necessary to isolate water-insoluble glucan synthesizing extracellular GTase from the culture supernatant of $S$. mutans MT8148, and determine whether or not cell-associated and extracellular GTases from the same strain are identical.

\section{REFERENCES}

Aoki, H., Shiroza, T., Hayakawa, M., Sato, S. \& KURAMITSU, H. K. (1986). Cloning of a Streptococcus mutans glucosyltransferase gene coding for insoluble glucan synthesis. Infection and Immunity 53, 587594.

Baba, T., Ogawa, T., OKahashi, N., Yakushiji, T., Koga, T., Morimoto, M. \& Hamada, S. (1986). Purification and characterisation of the extracellular D-glucosyltransferase from serotype $c$ Streptococcus mutans. Carbohydrate Research 158, 147-155.
BURNe, R. A., Rubinfeld, B., Bowen, W. H. \& YASBIN, R. E. (1986). Cloning and expression of a Streptococcus mutans glucosyltransferase gene in Bacillus subtilis. Gene 47, 201-209.

Coykendall, A. L. \& Gustafson, K. B. (1986). Taxonomy of Streptococcus mutans. In Molecular Microbiology and Immunology of Streptococcus mutans, pp. 21-28. Edited by S. Hamada, S. M. Michalek, H. Kiyono, L. Menaker \& J. R. McGhee. Amsterdam: Elsevier. 
CURTISs, R., III (1985). Genetic analysis of Streptococcus mutans virulence. Current Topics of Microbiology and Immunology 118, 253-277.

Furuta, T., Nisizawa, T., Chiba, J. \& Hamada, S. (1983). Production of monoclonal antibody against a glucosyltransferase of Streptococcus mutans 6715 . Infection and Immunity 41, 872-875.

HaMada, S. \& Slade, H. D. (1980). Biology, immunology and cariogenicity of Streptococcus mutans. Microbiological Reviews 44, 331-384.

HAMADA, S. \& TORII, M. (1978). Effect of sucrose in culture media on adherence to glass surfaces. Infection and Immunity 20, 592-599.

Hamada, S., Furuta, T., Okahashi, N., Nisizawa, T., Yamamoto, T. \& ChibA, J. (1984a). Characterization of a monoclonal antibody specific for lipoteichoic acid from various Gram-positive bacteria. Microbiology and Immunology 28, 1009-1021.

Hamada, S., Koga, T. \& OOShIma, T. (1984b). Virulence factors of Streptococcus mutans and dental caries prevention. Journal of Dental Research 63, 407-411.

Inoue, M., Koga, T., Sato, S. \& Hamada, S. (1982). Synthesis of adherent glucan by the concerted action of the two glucosyltransferase components of Streptococcus mutans. FEBS Letters 143, 101-104.

KeNNEY, A. C. \& Cole, J. A. (1983). Identification of a 1,3- $\alpha$-glucosyltransferase involved in insoluble glucan synthesis by a serotype $c$ strain of Streptococcus mutans. FEMS Microbiology Letters 16, 159162.

Koga, T., Asakawa, H., OKahashi, N. \& Hamada, S. (1986). Sucrose dependent cell adherence and cariogenicity of serotype $c$ Streptococcus mutans. Journal of General Microbiology 132, 2873-2883.

Kuramitsu, H. K. (1974). Characterization of cellassociated dextransucrase activity from glucosegrown cells of Streptococcus mutans. Infection and Immunity 10, 227-235.

KuRAmitsu, H. K. \& WondRaCK, L. (1983). Insoluble glucan synthesis by Streptococcus mutans serotype $c$ strains. Infection and Immunity 42, 763-770.
Mukasa, H. (1986). Properties of Streptococcus mutans glucosyltransferases. In Molecular Microbiology and Immunobiology of Streptococcus mutans, pp. 121-132. Edited by S. Hamada, S. M. Michalek, H. Kiyono, L. Menaker \& J. R. McGhee. Amsterdam: Elsevier. Mukasa, H., Shimamura, A. \& Tsumori, H. (1982). Purification and characterization of basic glucosyltransferase from Streptococcus mutans serotype $c$. Biochimica et biophysica acta 719, 81-89.

Muxasa, H., Tsumori, H. \& Shimamura, A. (1985). Isolation and characterization of an extracellular glucosyltransferase synthesizing insoluble glucan from Streptococcus mutans serotype $c$. Infection and Immunity 49, 790-796.

Pucci, M. J., Jones, K. R., Kuramitsu, H. K. \& MACRINA, F. L. (1987). Molecular cloning and characterization of the glucosyltransferase $\mathrm{C}$ gene ( $g t f C$ ) from Streptococcus mutans LM7. Infection and Immunity 55, 2176-2182.

Robeson, J. P., Barletta, R. G. \& Curtiss, R. (1983). Expression of a Streptococcus mutans glucosyltransferase gene in Escherichia coli. Journal of Bacteriology 153, 211-221.

RussELL, R. R. B. (1979). Glycosyltransferases of Streptococcus mutans strain Ingbritt. Microbios 23, 135-146.

SATo, S., KogA, T. \& INOUe, M. (1984). Isolation and some properties of extracellular D-glucosyltransferases and D-fructosyltransferases from Streptococcus mutans serotypes $c, e$, and $f$. Carbohydrate Research 134, 293-304.

ScotT, R. A., JR \& MelviN, E: H. (1953). Determination of dextran with anthrone. Analytical Chemistry 25, 1656-1661.

ShIROZA, T., Ueda, S. \& Kuramitsu, H. K. (1987). Sequence analysis of the $g t f B$ gene from Streptococcus mutans. Journal of Bacteriology 169, 4263-4270.

Zacharius, R. M., Zell, T. E., Morrison, J. H. \& WoODLOCK, J. J. (1969). Glycoprotein staining following electrophoresis on acrylamide gels. Analytical Biochemistry 30, 148-152. 